\section{Work From Home: Experiences and Future Challenges - Indian Perspectives from Pandemic Coronavirus and Consequent Lockdown}

\section{Kirti Makwana}

IIIM, Faculty of Management Studies, Charotar University of Science and Technology (Charusat), Gujarat, India, and

Govind B Dave

IIIM, Faculty of Management Studies, Charotar University of Science and Technology (Charusat), Gujarat, India

\begin{abstract}
Purpose- The Pandemic Coronavirus and consequent lockdown outbreak has called for "the largest Work - From - Home (WFH) experiment worldwide". Receiving huge numbers of personnel to Work-From-Home has not ever been crucial. WFH is recommended and implemented by approximately half (46\%) of organizations because of the COVID- 19 .

Design - This research paper did an in-depth study of WFH policies and explored experiences and challenges faced by employees. 260 executives working in 37 industries/sectors were approached through an online structured questionnaire.

Findings -Service Industries such as IT, Analytics, KPO, and Market Research are ready to implement Work from home.

Research limitations - The research study is limited to selected cities of Gujarat and Maharashtra states of India. The survey can be extended to other cities / states / countries. Practical implications - COVID - 19 has changed the experiences of being an employee or an HR. The results generated from the research, can be useful to provide inputs to the organizations, HR managers and strategic thinkers to take decisions about implementation, continuation and challenges of WFH arrangements as a long-term HR strategy in the coming future (in selected sectors/industries).

Social implications - Coronavirus, prompted major changes in life as Work from home (WFH) became the new normal. Employees embraced new routines and rules. The world saw its influence on all facets of life and has changed the way people work.

Originality- The distinctiveness of this article is that it provides evidences on how Indian workforce shifted to remote work in the months after the pandemic outbreak.

Keywords - Work-From-Home, COVID -19, Lockdown, Pandemic, WFH.

Paper type - Research paper.

\section{Introduction}

In 1973, an Engineer in NASA, Jack Nilles invented the term "telecommuting", which means the use of electronics to work remotely. At the time, he projected that 'telecommuting' style of work would become the norm and culture in about 20 years. In recent decades, telecommuting was pick up in many parts of the world, but in India, its reception has continued restricted. A majority of Indian companies do not permit work from home. The Pandemic Coronavirus and Consequent Lockdown outbreak have, though, made distant

1. On March 24, 2020, in response to Pandemic COVID -19 Prime Minister of India, Shri. Narendra Modi declared a complete nationwide lockdown, starting from midnight for 21 days. Further, On April 14, 2020, the Government of India extended nationwide lockdown till May 3, 2020. On 1 May, the Government of India further prolonged the lockdown by two weeks more till May 17, 2020. The nation is divided into three zones - Green, Red, and Orange Zones.

2. Coronavirus Disease (COVID-19) is an infectious communicable virus, which is caused by a recently exposed coronavirus.
\end{abstract}

Work From Home: Experiences and Future

Challenges 
working an inevitability overnight. During the nationwide lockdown, several Indian organizations have instructed and made compulsory their employees to Work - From - Home to socially distance individuals and lessen the spread of COVID -19 .

"Telework" / "Telecommuting" happens once Information Communication Technologies (ICT) helps to complete the work at a physical remoteness. Morgan (2004) found many studies mention that working from distant/remote places as "teleworking", "telecommuting" and "e-working". Nilles (2007) remarks to the "telework" is occupational travel in which bringing work to the worker as an alternative of workers to the work".

In the era of 21 st century, a flexible working system is Work - From - Home for the organisations. The Corona Virus Pandemic (COVID-19) has directed to the biggest number of workforces worldwide bound to work from home. People in most of the nations including India are commended to stay at home and to lessen community interactions. COVID -19 affected every segment of the economy. The concept of Work - From - Home got more acceptance at this point as most of the organisations across industries started introducing work from home in their HR policies. As the concept was newly introduced in India, the researchers tried to identify the preferences of work from home of Indian employees across various industries/sectors, and demographic variables.

\section{Literature review}

Work and personal life are supposed to be the utmost essentials in the life of a human (Toyin et al., 2016 ). Certainly, balancing professional and personal life is one of the greatest thoughtprovoking questions fronting families in the current era (Walker et al., 2008). The family has a significant role to play in encouraging and supporting the welfare of people and the social order. Friedman (2014) explained that "Four Circles" representing the four domains of one's life - "work, home, community, and self". He recommends adjusting the proportions of the spheres to replicate the value of each sphere. This supports replicate the "principles, goals, interests, activities and results" cultured in each area and whether the latter are well-matched or opposed to each other.

Grant et al. (2013) found that there has been a significant impact of technology on work, which makes it possible to work from home or any locations. Kurland and Bailyn (1999) briefed that work has turned into a "limitless activity", which can be carried out "anytime and anyplace". Toffler (1980), presented that flexibility in work can help to attain a balance between work and family. Kreiner et al. (2009) and Mayo et al. (2011), found that it is thought-provoking for workforces to attain a work/home balance. Grant-Vallone and Ensher (2011) explained that healthiness problems and personal / family problems can result from a struggle between work and home.

A study at Stanford University explored that work-from-home improves productivity in a big way. Previous research carried out by Harvard Business School, exhibited that WFH can reduce attrition rate by $50 \%$ when equated to office goers, whereas they stated considerable higher job satisfaction. Mothers with flexible working hours and work-from-home choices earn more money. The option of working remotely is more preferred at employees' end. A study conducted in the year 2017 releveled that, an average employee is agreeing to take $8 \%$ a lesser amount of salary for the possibility to work from home. This shows that employees give financial value to the flexibility given by a WFH policy.

\subsection{Work - from - home in various countries}

There remains to be every year's growth in corporations that offer flexible and remote working. A survey was conducted in the year 2019 by IWG Global Workplace Survey in which more than 15,000 executives across 80 countries participated. The survey found that $61 \%$ of multinationals are presently permitting their employees to have a remote working policy.

WFH in USA during covid - 19

As per the details of Global Workplace Analytics Research; ${ }^{3}$

3. https://globalworkplaceanalytics.com/ 


\begin{tabular}{|c|c|c|c|}
\hline $\begin{array}{l}\mathbf{5 0 \%} \text { of the US workforce have } \\
\text { a job which is compatible with } \\
\text { at least partial Work From } \\
\text { Home and } 20-25 \% \text { of the }\end{array}$ & $\begin{array}{l}80-90 \% \text { of the US workforce } \\
\text { like to work from home at least } \\
\text { part-time. To achieve Work } \\
\text { life balance they prefer } 2-3 \\
\text { days per week of concentrative }\end{array}$ & $\begin{array}{l}\text { Fortune } 1000 \text { organisations in } \\
\text { the world are revamping their } \\
\text { space around the fact that } \\
\text { employees are already mobile. } \\
\text { Studies repeated indicate that }\end{array}$ & $\begin{array}{r}\text { Work From Home: } \\
\text { Experiences and Future } \\
\text { Challenges } \\
78\end{array}$ \\
\hline frequency. & $\begin{array}{l}\text { work (home) and collaborative } \\
\text { work (in the office). }\end{array}$ & $\begin{array}{l}\text { they are not at their desk } 50 \\
60 \% \text { of the time. }\end{array}$ & \\
\hline
\end{tabular}

As per the statistical data of telecommuting, before COVID-19, in the year 2020, there were seven million people ( $43 \%$ of the employees) were already working from home in the US, which is 3.4 percent of the population. More $40 \%$ of US companies offered WFH as a choice than five years ago. The number of individuals who work from home has improved by $140 \%$ in the last fifteen years. As per Upwork 's "Future Workforce Report" by 2028, 73\% of US organizations will have e-workers. Further, $75 \%$ of current e-workers prefer to work remotely for the rest of their professional life.

WFH in $E U$

Work from home is used by a considerable percentage of workforces to balance their usual working activities in European countries.
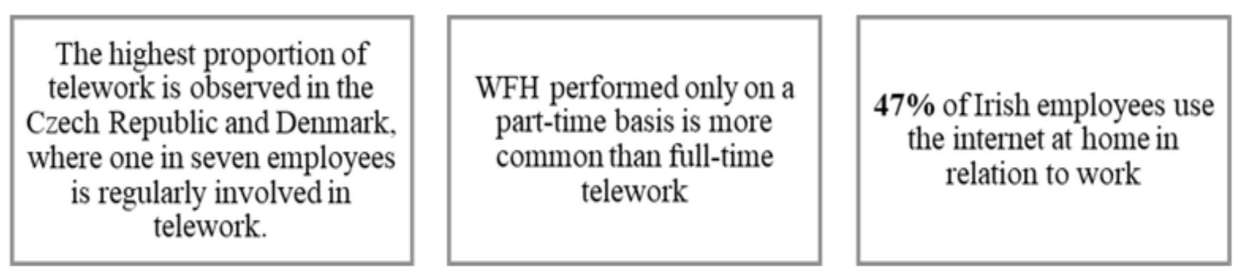

WFH in Great Britain

$50 \%$ of the United Kingdom's employees work from home by 2020 . A report published by UK's Office for National Statistics (April 2020) exhibited $49.2 \%$ of workforces were remotely working, as a consequence of the social distancing procedures announced in response to the COVID - 19.

\section{WHF in India}

Approximately half of India's technology employees ( 3 million) have already started to Work - From - Home as social distancing turns out to be crucial to contain the spread of the outbreak. During COVID - 19, Tata Consultancy Services (TCS) has requested more than $40 \%$ of its staff to work from home, while Accenture has encouraged over $60 \%$ of its staffs to work from home in India and the Philippines. About $58 \%$ of employees in India experienced work from home during COVID - 19 least once a week, representing that flexible office has touched a tipping point. In India, for generations, Indians just understood office-based work which comprises a static location and a $9-5$ schedule. But an unprecedented quantity of industries is now accepting a very different working model, which produces benefits for them and their workers.

\subsection{Advantages and disadvantage of working from home}

Effect of remote working on productivity

For most individuals and job categories, efficiency, and productivity is increased once there is a flexible workplace strategy. Unfettered from the noise, interruptions, power, and politics of an office/ workplace, most of the isolated employees practice improvement in performance when left to their devices.

4. Upwork is a worldwide freelancing stage where organizations and professionals connect and collaborate remotely.

5. https://economictimes.indiatimes.com/tech/ites/coronavirus-crisis-may-fast-forward-its-work-fromhome-adoption/articleshow/74766020.cms 


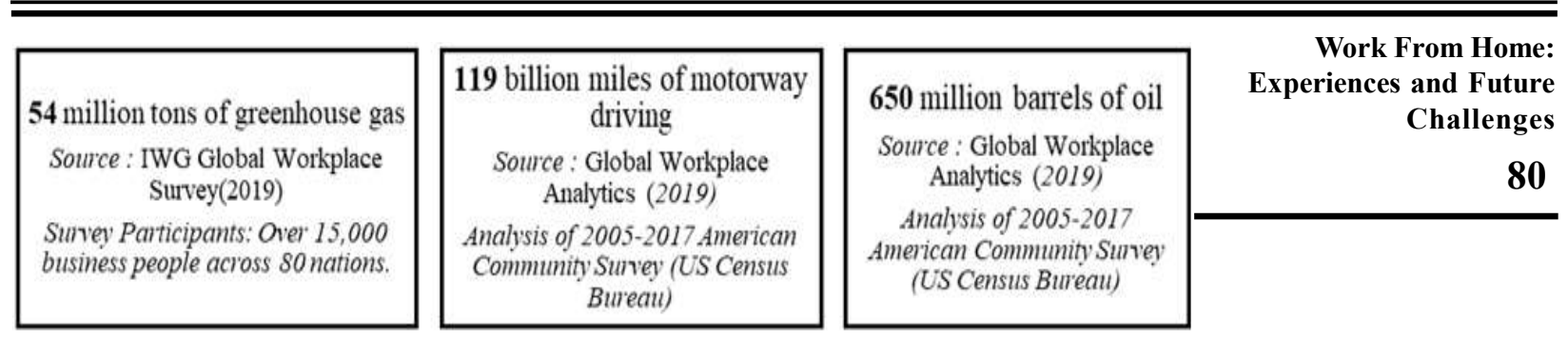

Disadvantages of work from home
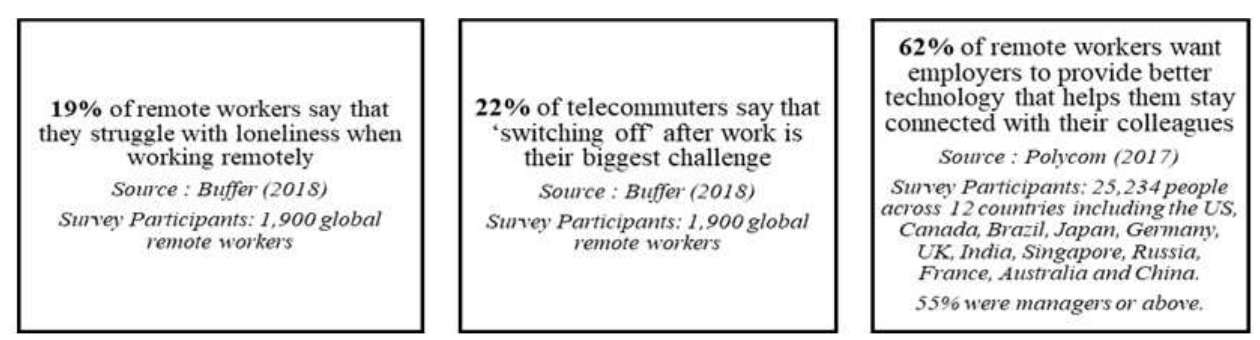

The Figure below represents a summary of the major optimistic and adverse sides of Work - From - Home Policy.

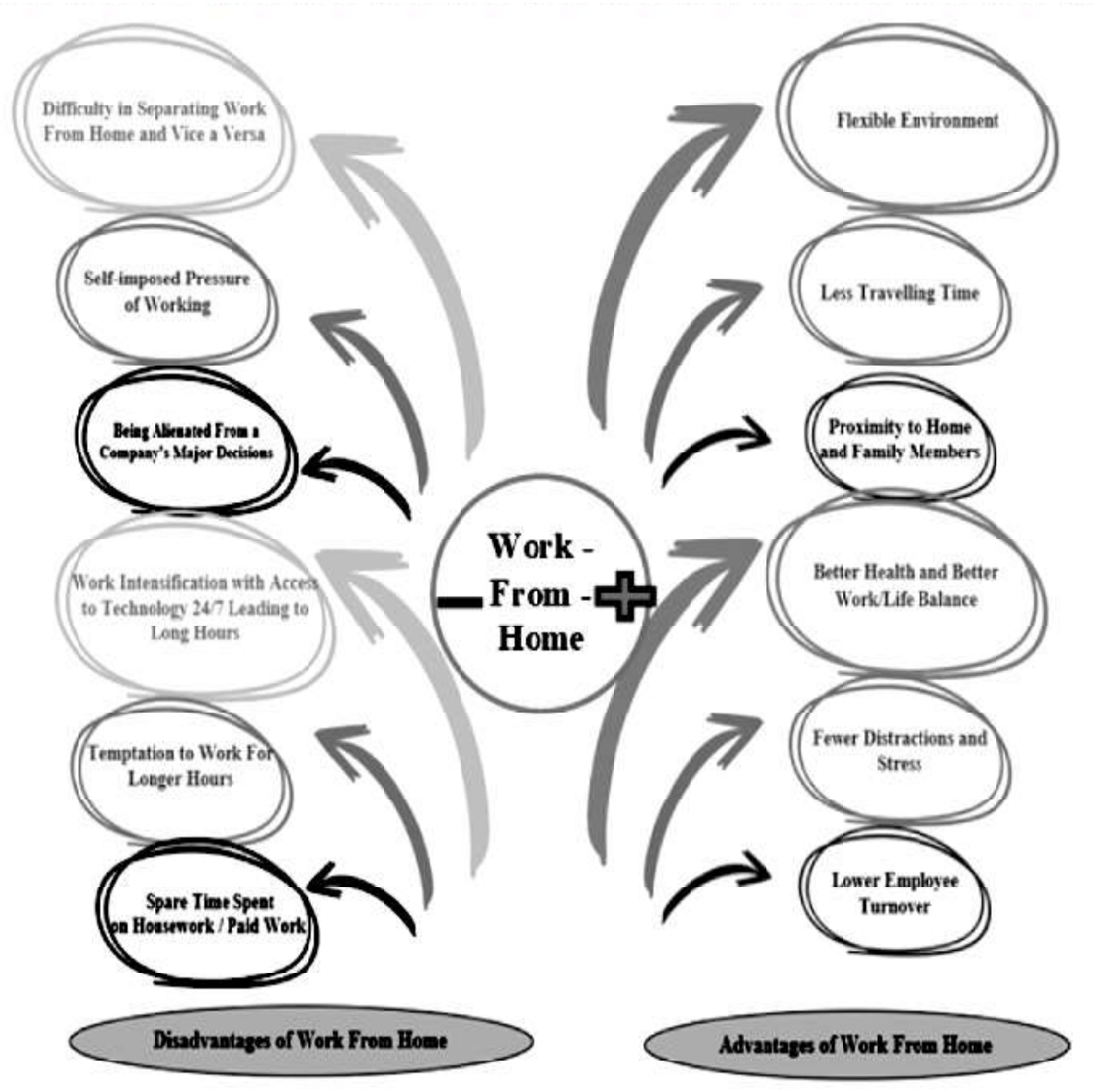

Figure 3. Advantages and Disadvantages of Work From-Home 


\begin{tabular}{l}
\hline GBR \\
Vol. 16 \\
81 \\
\hline
\end{tabular}

3. Objectives

During the COVID-19 pandemic, the term "Work - From - Home" was a new norm and term for the Indian organizations as a temporary, alternative working arrangement. The researchers screened meticulously for evidence representing that certain industries and sectors had started WFH at scale. To explore new experiences of employees, the following objectives were attained in this research paper:

- To identify the preferences of WFH of Indian employees across various industries/ sectors, and demographic variables like age, gender, marital status, family background.

- To explore experiences and future challenges of work from home experiment from Indian perspectives from pandemic Coronavirus and consequent lockdown.

3.1 Hypotheses of the study

There is no significant relationship between preference and experiences of work from home and gender | age | type of industry/sector | Family Background of employees.

\section{Research methodology}

In the present study, a survey approach under descriptive research was adopted.

\subsection{Sample}

Stratified random sampling was used by introducing introductory questions about experiencing work from home for the first time, additionally, Convenience sampling was adopted in the selection of samples to be studied. 260 executives working in 37 industries/ sectors were part of the study.

\subsection{Instrument and procedure}

On online structured questionnaire was used. A total of 400 questionnaires/emails were circulated through Email, LinkedIn, and Social Media after taking their due consent. The test was not time-bound. However, each respondent took approximately an average of fifteen minutes to fill the questionnaire. The emails/responses were collected back. Out of 400 questionnaires distributed, 260 valid responses were received. Cronbach's alpha value for the instrument is 0.88 , which shows a high level of internal consistency for the scale developed with this specific sample.

\subsection{Statistical tools used}

Frequency, percentage, ANOVA, Cluster, and Discriminant Analysis tests were used to analyze the data.

The figure below shows the Dependent and Independent variables that are taken into consideration for the research work. 


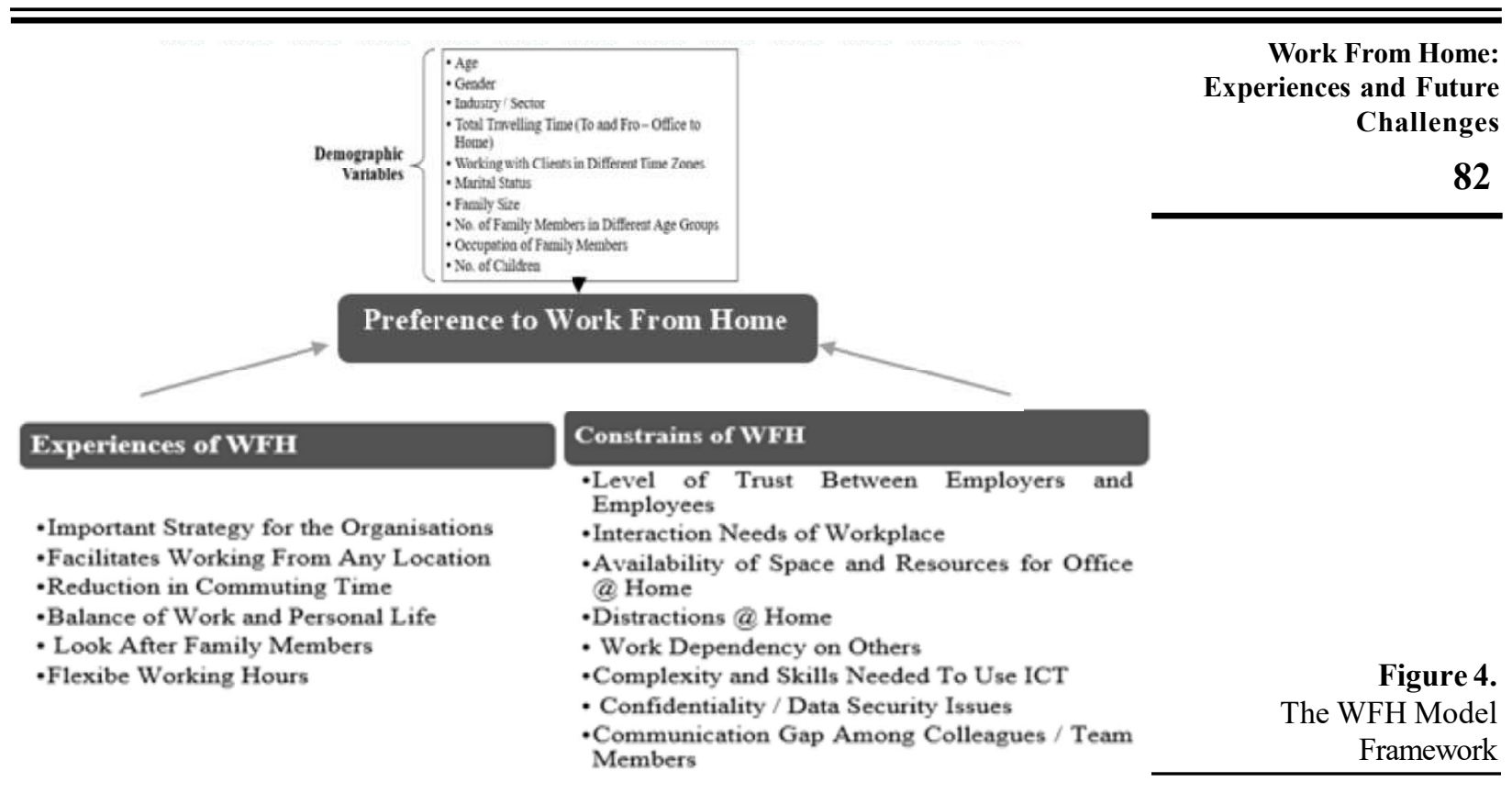

\section{Data analysis}

As shown in Figure - 5, 63.8\% (166 out of 260) of respondents belonged to the age group of 22 - 30 age group. Approximately $80 \%$ of the respondents belonged to the age group of 22 - 35 years. Only five (5) respondents were part of 46-50 years and $>50$ years age groups.

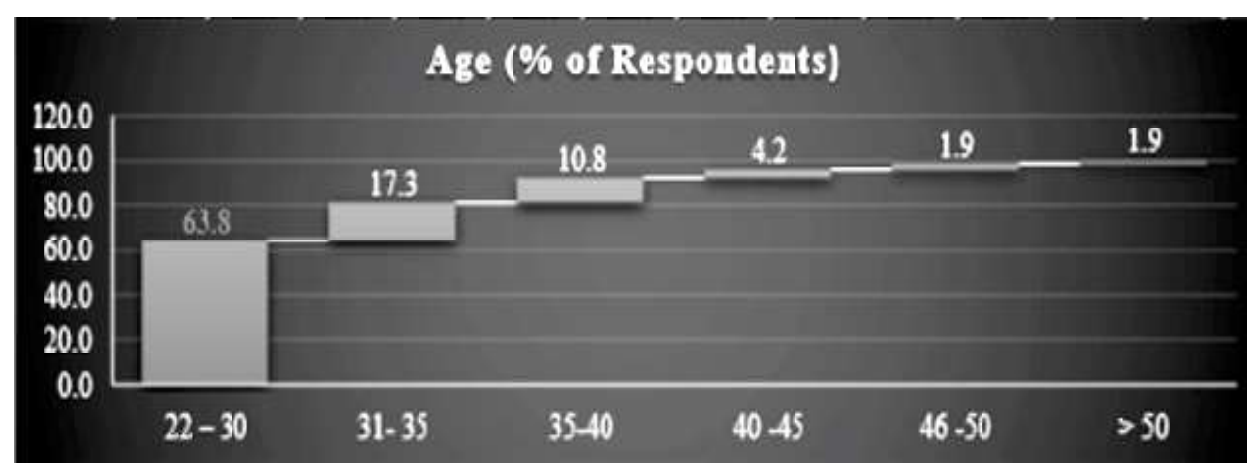

Figure 5. $\%$ of Respondents by Age

Group

\begin{tabular}{|l|c|c|}
\hline Gender & Frequency & Percent \\
\hline Male & 188 & 72.3 \\
\hline Female & 72 & 27.7 \\
\hline
\end{tabular}

Table 1. Gender Details

$72.3 \%$ (188 respondents) were males while $27.7 \%$ ( 72 respondents) were female employees.

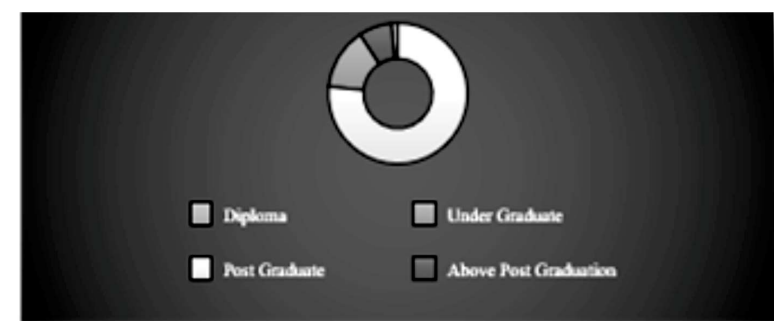

Figure 6. $\%$ of Respondents by Qualifications 


\begin{tabular}{l|l|c|c|}
\hline \hline $\begin{array}{l}\text { GBR } \\
\text { Vol. 16 }\end{array}$ & Qualification & Frequency & Percent \\
\cline { 3 - 4 } & Diploma & 4 & 1.5 \\
\hline \multirow{3}{*}{$\begin{array}{l}\text { Table 2. } \\
\text { Qualification Details }\end{array}$} & Under Graduate & 37 & 14.2 \\
\hline & Post Graduate & 199 & 76.5 \\
\cline { 2 - 4 } & $\begin{array}{l}\text { Above Post } \\
\text { Graduation }\end{array}$ & 20 & 7.7 \\
\hline
\end{tabular}

As shown in Figure 6 and table 2, 76.50\% (199 respondents) of respondents had Post Graduation as their highest qualification. Whereas, only $1.5 \%$ of the respondents had a Diploma as their highest qualification. $20.00 \%$ of respondents had qualifications above Post Graduation (i.e - Doctor of Philosophy (Ph.D.) or equivalent).

As shown in Figure - 7, 19.6\% (51) of respondents were from the Information and Technology sector, which is the highest among all the sectors. Whereas, $16.9 \%$ (44) respondents were from the Education sector. However, $28.5 \%$ (74) respondents were from other sectors (which includes 29 various sectors/industries, e.g. Chemica, Export - Import, Kitchen Appliances, Oil and Gas, Paints, Pipe Industry, Ports and Logistics, Printing, Textile, Transport and Logistics, Adhesives and Chemicals, Beauty Products, Electronics, Market Research, Plywood, Power and Infrastructure, Real Estate, Renewable Energy, E-Commerce, Health Care, Management Consulting, Petrochemical, Food and Beverages, Knowledge Process Outsourcing (KPO), Retail, Telecommunication, Tourism and Hospitality, Automobile and Pharmaceutical).

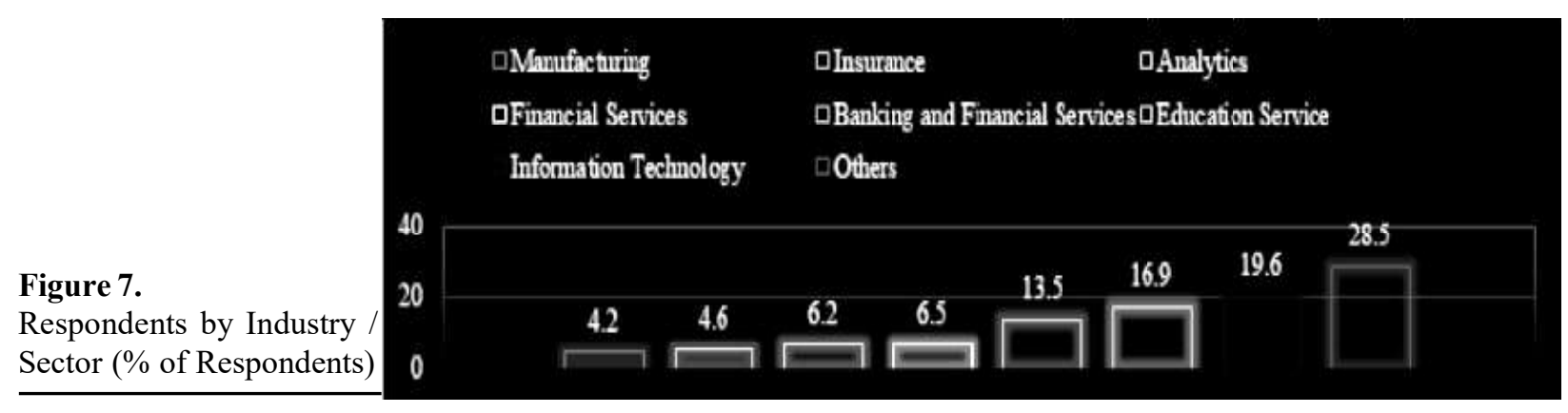

Figure 8.

Average Hours /Day Spent in Office Premises (\% of Respondents)

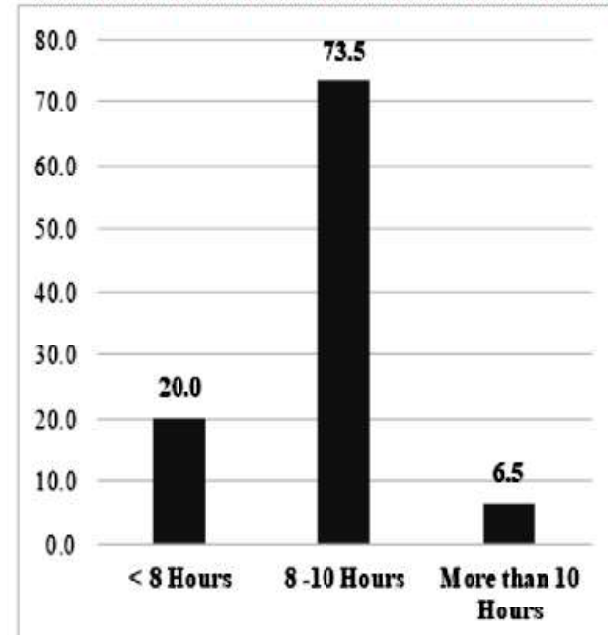

Figure 9. Total Travelling Time/Day (To and Fro - Office to Home) (\% of Respondents)

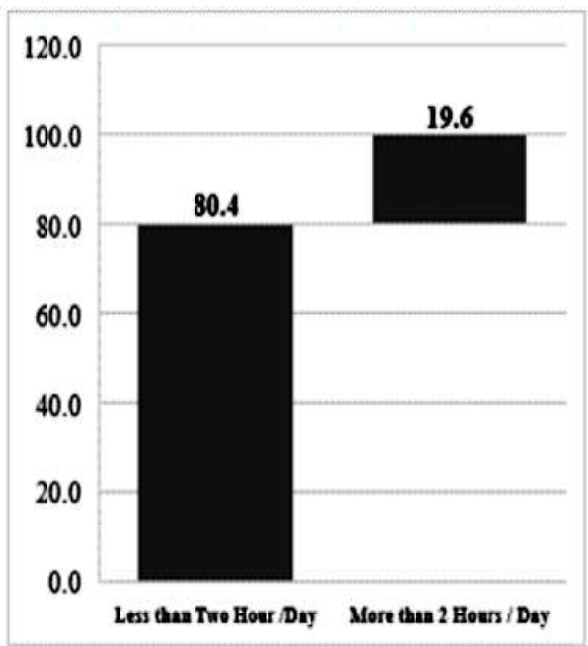


$73.5 \%$ of the respondents (191) spend approximately $8-10$ hours a day in their $9-5$ traditional static office location and $80.4 \%$ (209) respondents travel/ commute for less than two hours /day (to and fro - Office to home) whereas, 19.6\% of respondents have to travel more than two hours per day to reach office/home.

As shown in Figure - 10, the majority of the respondents were from the western part of India (Gujarat and Maharashtra). Approximately $70 \%$ of the respondents were from major cities of Gujarat (i.e. Ahmedabad, Vadodara, Surat, Gandhinagar, and Rajkot). $10 \%$ of the respondents were from major cities of Maharashtra (Mumbai and Pune) and 20\% of respondents were from other major cities of India such as Bhopal, Delhi/Gurugram, Greater Noida, Hyderabad, Kolkata, Gurgaon, Kochi, Bangalore, Chennai.

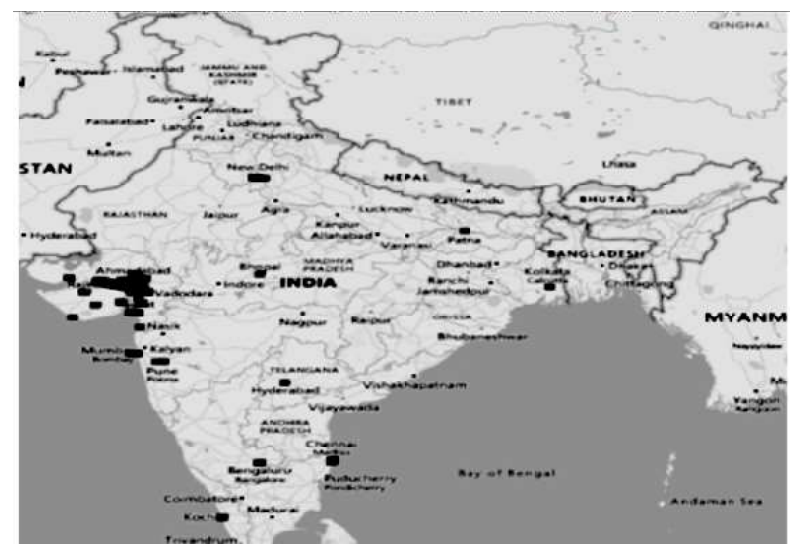

Figure 10.

Geographic Spread of Respondents

The respondents have an average work experience of 6.95 years, with minimum one $(01)$ and a maximum of forty-five (45) years. The details are given in table no. 3 .

\begin{tabular}{|l|r|}
\hline Mean & 6.95 \\
\hline Standard Deviation & 6.54 \\
\hline Minimum & 1.0 \\
\hline Maximum & 45.0 \\
\hline
\end{tabular}

Table 3.

Total No. of Years of Experience

\begin{tabular}{|c|c|c|}
\hline Response & Frequency & Percent \\
\hline Yes & 140 & 53.8 \\
\hline No & 120 & 46.2 \\
\hline
\end{tabular}

Table 4.

Working with Different Time Zone

\begin{tabular}{|c|c|c|}
\hline Status & Frequency & Percent \\
\hline Unmarried & 112 & 43.1 \\
\hline Married & 148 & 56.9 \\
\hline
\end{tabular}

Table 5. Marital Status

Out of 260 respondents, 140 respondents $(53.8 \%)$ work with different time zones with their clients. While $46.2 \%$ of respondents do not have to deal with different time zone issues. $43.1 \%$ (112) respondents were married and 56.9\% (148) were unmarried. As shown in table 6 , $56.20 \%$ (146) respondents were nuclear families. While $38.10 \%$ (99) were living in a joint family. Type of family is a crucial factor to opt for Work - From - Home as in nuclear family male and female counterparts have to complete all the responsibilities of household matters and issues. Moreover, 53.8\% (140) respondents have 4-6 family members in their family. It is clear from the data that, Work - From - Home shall facilitate to take care of the issues related to household and family members/emergencies. 


\begin{tabular}{|c|c|c|}
\hline $\begin{array}{c}\text { Type of } \\
\text { Family }\end{array}$ & Frequency & Percent \\
\hline Nuclear & 146 & 56.2 \\
\hline Joint & 99 & 38.1 \\
\hline Extended & 15 & 5.8 \\
\hline
\end{tabular}

\section{Table 6.}

Family Type

Table 7.

Family Size (No. of Members)

\begin{tabular}{|c|c|r|}
\hline No.: & Frequency & Percent \\
\hline $\mathbf{1}-\mathbf{3}$ & 92 & 35.4 \\
\hline $\mathbf{4 - 6}$ & 140 & 53.8 \\
\hline $\mathbf{7 - 9}$ & 17 & 6.5 \\
\hline More than 9 & 11 & 4.2 \\
\hline
\end{tabular}

Table 8.

Children Details (Number of Boy and Girl Child)

\begin{tabular}{|l|c|c|c|c|}
\hline \multicolumn{3}{|c|}{ No. of Girls } & \multicolumn{2}{c|}{ No. of Boys } \\
\hline No.: & Frequency & Percent & Frequency & Percent \\
\hline 0 & 92 & 62.2 & 92 & 62.16 \\
\hline $1-2$ & 51 & 34.5 & 56 & 37.8 \\
\hline 3 or More & 5 & 3.4 & 0 & 0 \\
\hline Total & $\mathbf{1 4 8}$ & $\mathbf{1 0 0 . 0}$ & $\mathbf{1 4 8}$ & $\mathbf{1 0 3}$ \\
\hline
\end{tabular}

Table 8 depicts that, out of 148 married respondents, $37.9 \%$ (56) respondents had girl child whereas, $37.9 \%$ (56) respondents had at least one boy.

\begin{tabular}{|c|c|c|c|c|c|c|c|c|c|c|c|c|}
\hline \multirow[t]{2}{*}{$\begin{array}{c}\text { No. of } \\
\text { Members }\end{array}$} & \multicolumn{2}{|c|}{$\begin{array}{l}\text { Children } \\
\text { (0-2 Years) }\end{array}$} & \multicolumn{2}{|c|}{$\begin{array}{c}\text { Child } \\
\text { (3-16 Years) }\end{array}$} & \multicolumn{2}{|c|}{$\begin{array}{c}\text { Young } \\
\text { Adults } \\
\text { (17-30 } \\
\text { Years) }\end{array}$} & \multicolumn{2}{|c|}{$\begin{array}{c}\text { Middle Age } \\
\text { Adults } \\
\text { (31 -45 } \\
\text { Years) }\end{array}$} & \multicolumn{2}{|c|}{$\begin{array}{c}\text { Old Adults } \\
(45-60 \\
\text { Years })\end{array}$} & \multicolumn{2}{|c|}{$\begin{array}{c}\text { Senior } \\
\text { Citizens } \\
\text { (Above 60 } \\
\text { Years) }\end{array}$} \\
\hline & $\mathbf{F}$ & $\%$ & $\mathbf{F}$ & $\%$ & $\mathbf{F}$ & $\%$ & $\mathbf{F}$ & $\%$ & $\mathbf{F}$ & $\%$ & $\mathbf{F}$ & $\%$ \\
\hline $\mathbf{0}$ & 215 & 82.7 & 184 & 70.8 & 81 & 31.2 & 136 & 52.3 & 110 & 42.3 & 157 & 60.4 \\
\hline 1 & 37 & 14.2 & 58 & 22.3 & 68 & 26.2 & 37 & 14.2 & 36 & 13.8 & 44 & 16.9 \\
\hline 2 & 4 & 1.5 & 13 & 5.0 & 64 & 24.6 & 75 & 28.8 & 101 & 38.8 & 49 & 18.8 \\
\hline 3 & 4 & 1.5 & 2 & 0.8 & 35 & 13.5 & 7 & 2.7 & 7 & 2.7 & 7 & 2.7 \\
\hline 4 or More & 0 & 0 & 3 & 1.2 & 12 & 4.6 & 5 & 1.9 & 6 & 2.3 & 3 & 1.2 \\
\hline
\end{tabular}

Age Group of Family

Members

Table 9 represents that, $17.2 \%(45)$ respondents have at least one baby with an age group of 0 - 2 years in their family, while $29.3 \%$ (76) respondents have children with an age group of 3-16 years. $68.9 \%$ (179) respondents have at least one young adult in the family with an age group 17-30 years. $47.6 \%$ (124) respondents have middle-age adults with age group 31-45 years, while $57.6 \%$ (150) and 39.6\% (103) respondents have old adults with age group 45-60 years and senior citizens respectively. It is noteworthy that, $46.5 \%$ (121) respondents have babies and child and $97.2 \%$ (253) respondents have old adults and senior citizens in their family. Work - From - Home policy will be a blessing for the Indian employees to take care of babies, children, and old age citizens balancing their professional work.

As shown in Table - 10, respondents were strongly agreeing with the fact that, Work - From - Home concept has become an import strategy for the organizations during COVID - 19, nationwide lockdown (with mean value 4.46 on a scale of 5). Whereas, respondents were more on the neutral side to note the improvement in productivity and performance by working from home (with mean 3.38 and standard deviation 1.14 on a scale of 5). 


\begin{tabular}{|l|c|c|}
\hline \hline \multicolumn{1}{|c|}{ Statement } & Mean & $\begin{array}{c}\text { Standard } \\
\text { Deviation }\end{array}$ \\
\hline $\begin{array}{l}\text { Work - From - Home (WFH) concept has become an increasingly important strategy } \\
\text { for the organi zations during COVID - 19, Nationwide Lockdown. }\end{array}$ & 4.46 & 0.87 \\
\hline WFH facilitates working from any location. & 4.15 & 1.11 \\
\hline There is a signifi cant reduction in time spent on commuting to the office & 4.07 & 1.13 \\
\hline WFM has led to a decrease in physical conveyance and urban congestion & 3.97 & 1.13 \\
\hline WFM has led to reductions in pollution and energy use & 4.06 & 1.13 \\
\hline $\begin{array}{l}\text { WFM has led to reductions in Workplace asso ciated costs (Transportation, Food, } \\
\text { Attire, etc.) }\end{array}$ & 3.90 & 1.17 \\
\hline $\begin{array}{l}\text { I can well balance my professional and personal life by removing traveling time } \\
\text { and/or making adjustments in my working hours to personal needs. }\end{array}$ & 3.82 & 1.07 \\
\hline WFH has helped me to look after young c hildren and/or parents. & 4.02 & 1.06 \\
\hline I feel WFH improved productivity and performance. & 3.38 & 1.14 \\
\hline WFH created chances for both extended and more flexibl e working hours. & 3.90 & 1.09 \\
\hline $\begin{array}{l}\text { I get the flexibility to start working earl y or later or complete my work earl ier or } \\
\text { later }\end{array}$ & 3.88 & 1.11 \\
\hline There is a possible improvement in work-life balance. & 3.77 & 1.03 \\
\hline
\end{tabular}

$\begin{array}{r}\begin{array}{r}\text { Work From Home: } \\ \text { Experiences and Future } \\ \text { Challenges } \\ 86\end{array} \\ \hline\end{array}$

Table 10.

Mean and Standard

Deviation of Work - From -

Home Experiences

\begin{tabular}{|l|c|c|}
\hline \multicolumn{1}{|c|}{ Statement } & Mean & $\begin{array}{c}\text { Standard } \\
\text { Deviation }\end{array}$ \\
\hline It is Possible to imp lement WFH in my organi zation regularly (fully / partially). & 3.12 & 1.32 \\
\hline $\begin{array}{l}\text { I would expect and recommend my HR Dept. to change the HR Policy and bring the } \\
\text { WFH concept soon. }\end{array}$ & 3.32 & 1.28 \\
\hline I would prefer Regular home -based telework. & 3.00 & 1.22 \\
\hline I would prefer occasional home -based telework (once / twice in a week) & 3.76 & 1.15 \\
\hline $\begin{array}{l}\text { The m ost preferred WFH day is the last working day of the week. (Friday / } \\
\text { Saturday) }\end{array}$ & 3.87 & 1.23 \\
\hline Most preferred WFH day is the first working day of the week. (Monday) & 2.57 & 1.42 \\
\hline
\end{tabular}

Table 11.

Mean and Standard Deviation of Statements

Related to Prospect / Preference of Work - From - Home

Respondents are now expecting and ready to recommend Work - From - Home Policy to be introduced in their HR policy.

\begin{tabular}{|l|c|c|}
\hline \multicolumn{1}{|c|}{ Statement } & Mean & $\begin{array}{c}\text { Standard } \\
\text { Deviation }\end{array}$ \\
\hline $\begin{array}{l}\text { Level of trust between managers and employees. (Managers are often suspicious of } \\
\text { teleworkers. Out of sight, they doubt that the teleworkers are slacking off') }\end{array}$ & 3.42 & 1.12 \\
\hline Self-perceived job sustainability & 3.55 & 0.91 \\
\hline Workplace interaction needs & 3.91 & 1.01 \\
\hline $\begin{array}{l}\text { Availability of office space and resources and lack of ass istance to troubleshoot the } \\
\text { issues at home }\end{array}$ & 3.78 & 1.04 \\
\hline $\begin{array}{l}\text { Distractions at Home (Temptations at home from television, computer, phone, etc, } \\
\text { Noise at Home) }\end{array}$ & 3.72 & 1.17 \\
\hline $\begin{array}{l}\text { Increased responsibility to monitor the working time of employees which makes time } \\
\text { management more complex. }\end{array}$ & 3.68 & 1.08 \\
\hline Work dependency on others & 3.53 & 1.12 \\
\hline Difficulty and skills needed to use ICT effectively during WFH. & 3.60 & 1.06 \\
\hline Confidentiality / Data Security Issues & 3.62 & 1.18 \\
\hline Increased communication gap among colleagues/ team members. & 3.65 & 1.22 \\
\hline
\end{tabular}

The main challenge faced by the respondents to implement work from home in the future is the requirement of workplace interactions need. Most of the respondents responded that their workplace interactions need is not satisfied by working from home. They felt they can easily solve small issues/hurdles by being in close proximity. Solving these issues by working from remote places increase their efforts, follow-ups, and requires more coordination. Other major challenges are the availability of office space and resources at home. Further, the respondents also lack with the assistance and support for ICT troubleshoot at home. Additionally, respondents also feel more distractions at home. They get more temptations from television, computer, phone, etc. As 38.1\% (99) and 5.8\% (15) respondents live in Joint and Extended families respectively, noise at home is a significant distraction.

The least affecting challenge is the level of trust between managers and employees. Most of the respondents were disagreeing with the fact that managers are distrustful of teleworkers. They do not agree with the concept of out of sight is out of mind. 


\begin{tabular}{|c|c|c|c|c|c|c|}
\hline \multicolumn{7}{|l|}{ GBR } \\
\hline Vol. 16 & & Sum of Squares & df & $\begin{array}{l}\text { Mean } \\
\text { Square }\end{array}$ & F & Sig. \\
\hline 87 & Between Groups & 52.48 & 36 & 1.45 & 0.819 & 0.759 \\
\hline Table 13 & Within Groups & 396.81 & 223 & 1.77 & & \\
\hline
\end{tabular}

Possibility to Implement

WFH on Regular Basis -

Across Industries

The value of $F$ is 0.819 , which reaches significance with a p-value of 0.759 (which is greater than the 0.05 alpha level). This shows that there is no statistically significant difference between the means of possibilities of implementation of work from home across industries.

Table 14.

Possibility to Implement

WFH on Regular Basis

Across Industries

Designation

\begin{tabular}{|l|c|c|c|c|c|}
\hline & Sum of Squares & df & Mean Square & F & Sig. \\
\hline Between Groups & 57.21 & 42 & 1.36 & 0.754 & 0.862 \\
\hline Within Groups & 392.09 & 217 & 1.80 & & \\
\hline
\end{tabular}

The value of $F$ is 0.754 , which reaches significance with a $p$-value of 0.862 (which is greater than the 0.05 alpha level). This shows that there is no statistically significant difference between the means of possibilities of implementation of work from home regularly (fully / partially) across various designations. To generate natural grouping across industries and geographic spread about the preference of regular based work from home Policy implementation, the two-step cluster analysis procedure is applied.

The cluster pie chart from Figure 11 demonstrates the comparative size for four clusters solution.

Figure 11.

Cluster Analysis Details

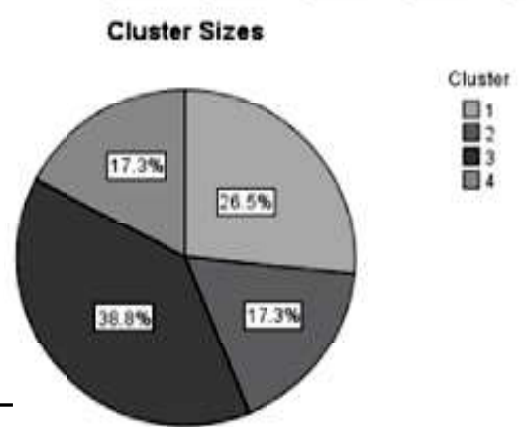

\begin{tabular}{|c|c|}
\hline Size of Smallest Cluster & $45(17.3 \%)$ \\
\hline Size of Largest Cluster & $101(38.8 \%)$ \\
\hline $\begin{array}{l}\text { Ratio of Sizes: } \\
\text { Largest Cluster to } \\
\text { Smallest Cluster }\end{array}$ & 2.24 \\
\hline
\end{tabular}

As shown in Figure 12, Information Technology, Software Development, Analytics, Banking, and Financial Services, Education Services, Insurance, Knowledge Process Outsourcing, and Market Research are the major industries/sectors in which employees see more possibility to implement work from home in future. Whereas, Chemical, Automobile, Electronics, Export - Import, Manufacturing, and Piping Industries are the traditional industries in which employees would like to prefer less regular work from home. 


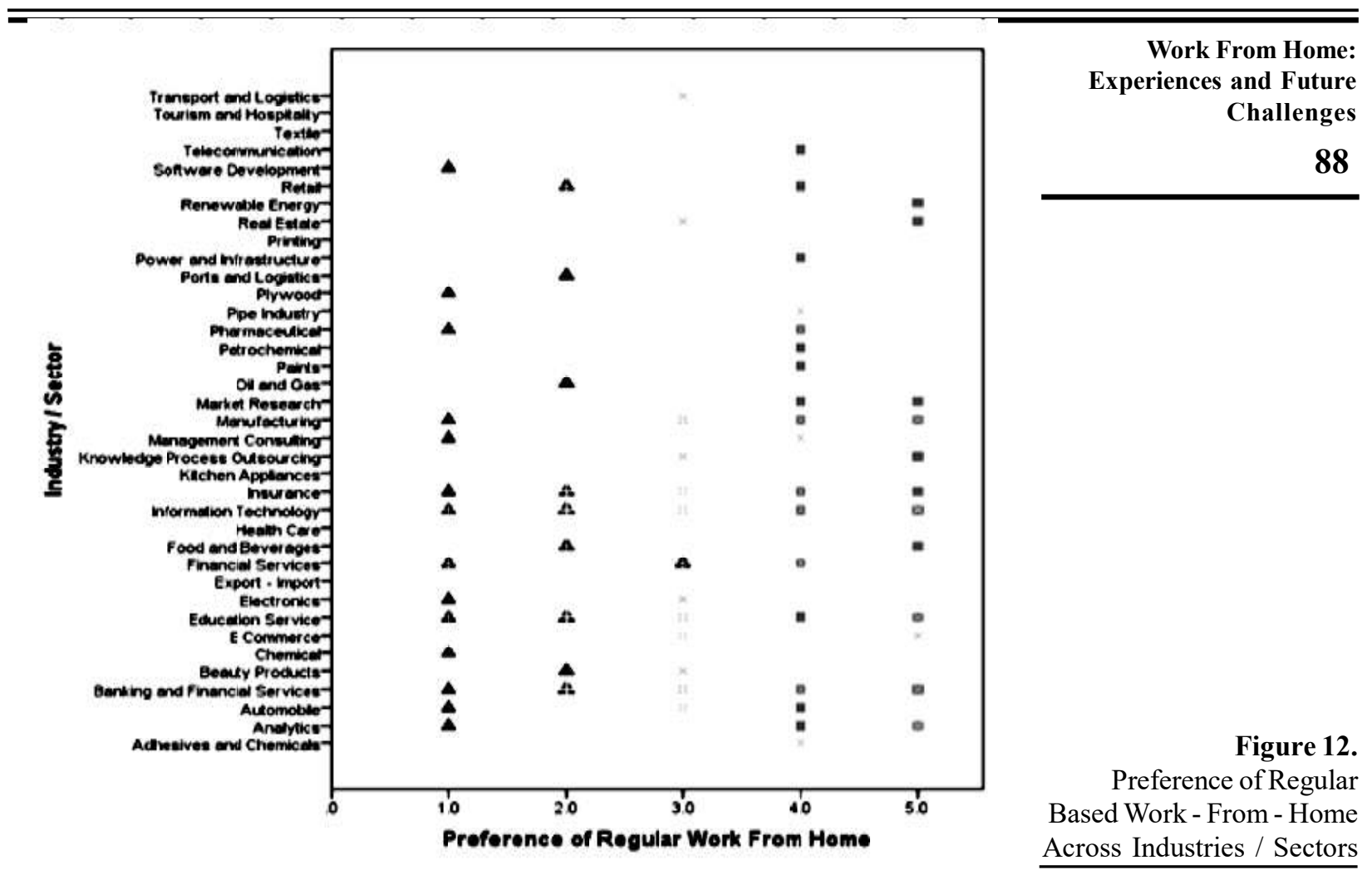

A discriminant function analysis was applied to evaluate how well an employees' experiences, preferences, and challenges perceived could be predicted using three discriminant independent variables. These three discriminating independent variables are working with different industries/sectors, individual's designations, and average hours spent in the office. The subsequent step by step procedure was carried out before presenting the "Group Centroids" of all the independent variables: Test of Equality of Means ' Variables in the Analysis ' Variables entered and removed ' Eigenvalues ' Wilks' Lambda ' Standardized Canonical Discriminant Function Coefficients ' Structure Matrix ' Functions at Group Centroids.

This figure is the scatter plot of all the Industries / Sectors, Office Hours Spent, and Designations (each group represented by a corresponding number and large squares) on function 1 and function 2. It also shows the scatter of individual variables against its' corresponding value with small circles. The classification of the same brought out certain interesting facts which are as mentioned below:

\begin{tabular}{|l|l|}
\hline \multicolumn{1}{|c|}{ Selected Variables } & \multicolumn{1}{c|}{ Relations } \\
\hline Industry / Sector & Highest on Function 1 \\
\hline Designation & Highest on Function 1 \\
\hline The average number of hours spent in the office & Highest on Function 1 \\
\hline
\end{tabular}

It can be seen from figure 13, that Information Technology, Software Development, Analytics, Banking, and Financial Services, Education Services, Insurance, Knowledge Process Outsourcing, and Market Research are the Industries / Sectors closer to Group Centroids, whereas, Chemical, Automobile, Electronics, Export - Import, Manufacturing and Piping Industries are going far from the Group Centroids. The same is the case with Number of Hours Spending in office, respondents spending more than 10 hours in the office are getting far from the Group Centroid. Figure 15 shows that traditional designations such as Accountants, Branch Managers, Accounting Executives (employees involved in cash transactions), experiences, preferences, and challenges perceived by them for work from home differ signifying from other designations. 


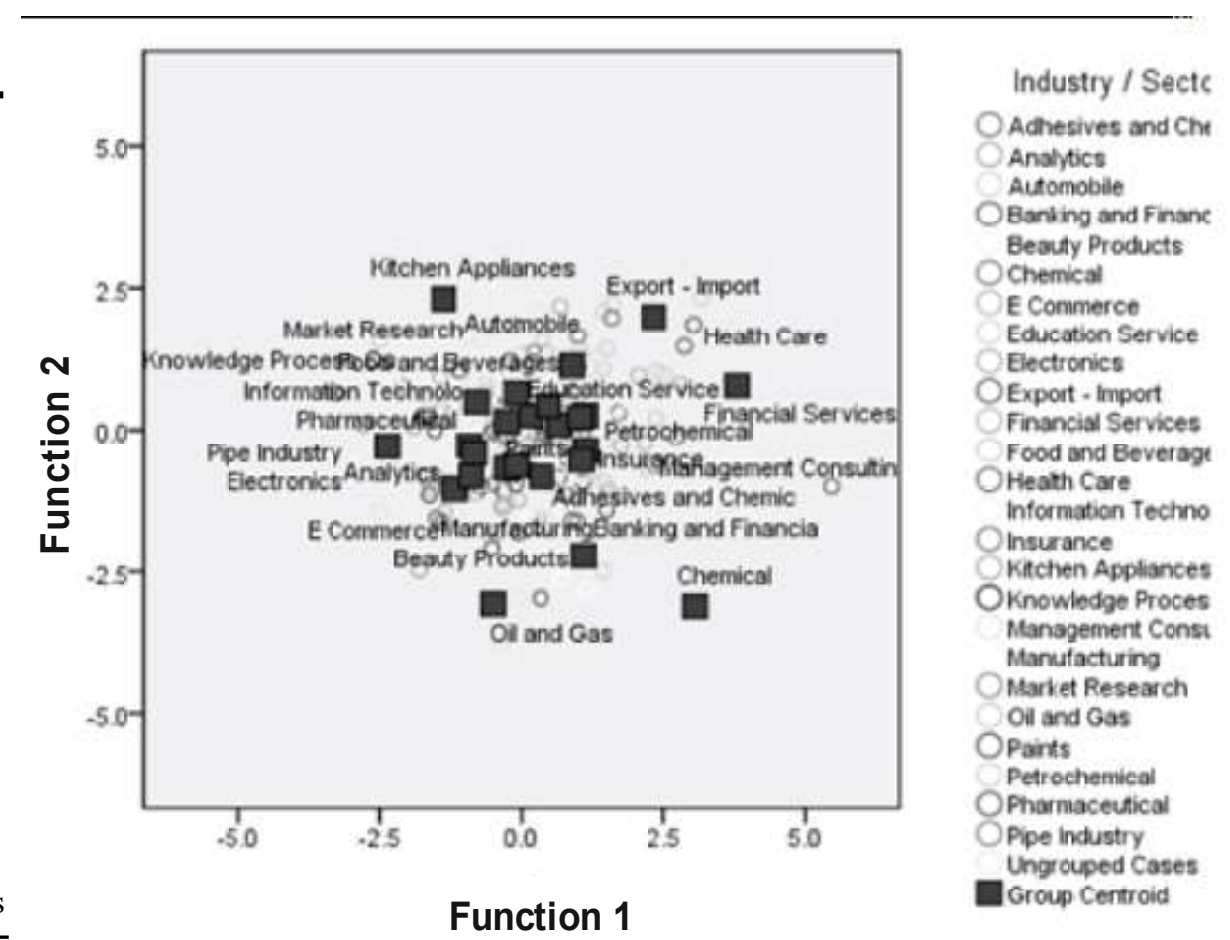

Figure 13.

Discriminant Analysis of Work - From - Home

Across Industries / Sectors

\section{Function 1}

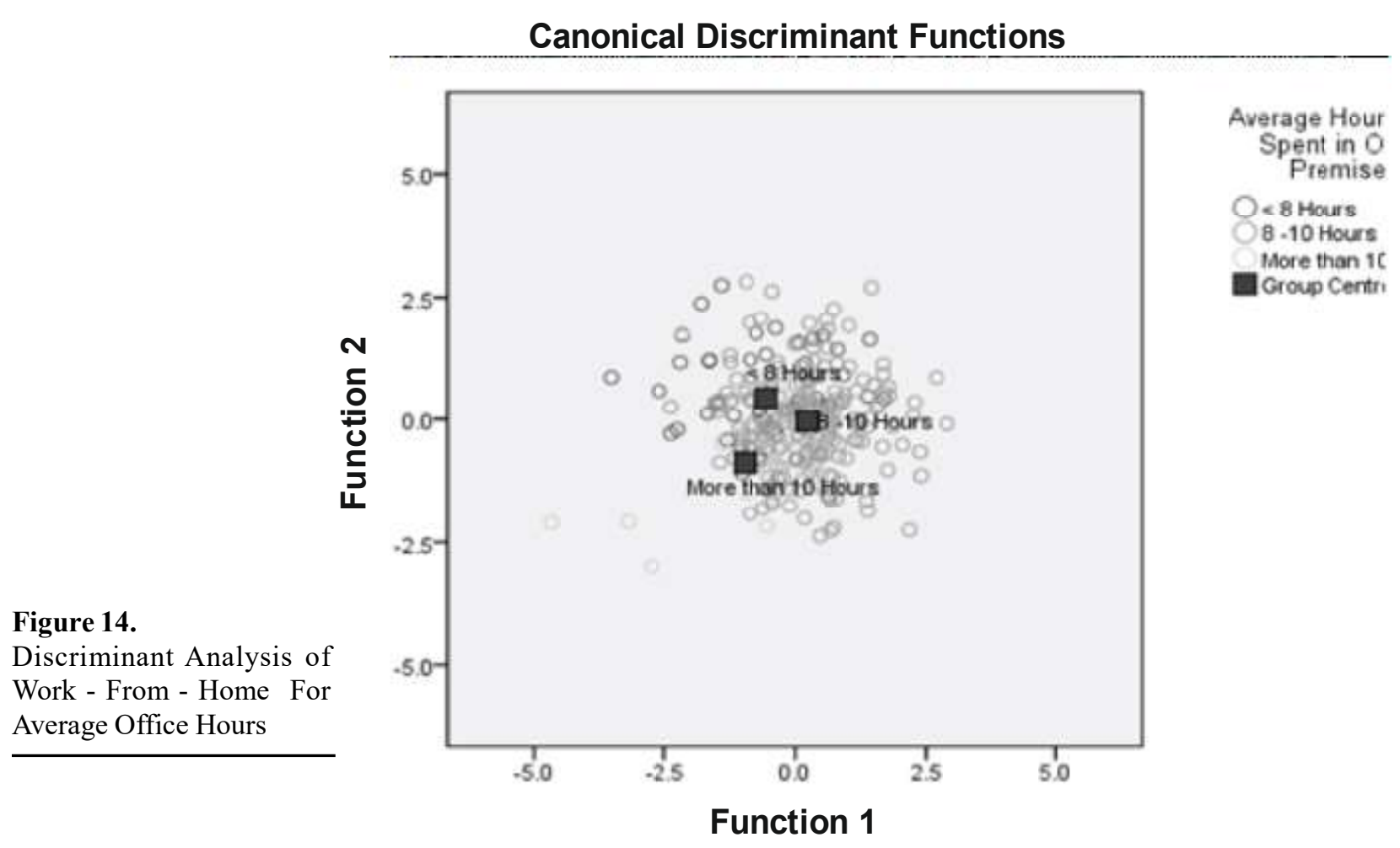

Figure 14.

Discriminant Analysis of Work - From - Home For Average Office Hours

\section{Canonical Discriminant Functions}
Andybics
Banting and Finane
Beauty Products
E Commerce
Education Service
Financial Service:
ood and Beverag
Heath Care
insurance
Appliances
Knowledge Proces
Manufacturing
Paints
Pipe industry

Ungrouped Cases

s




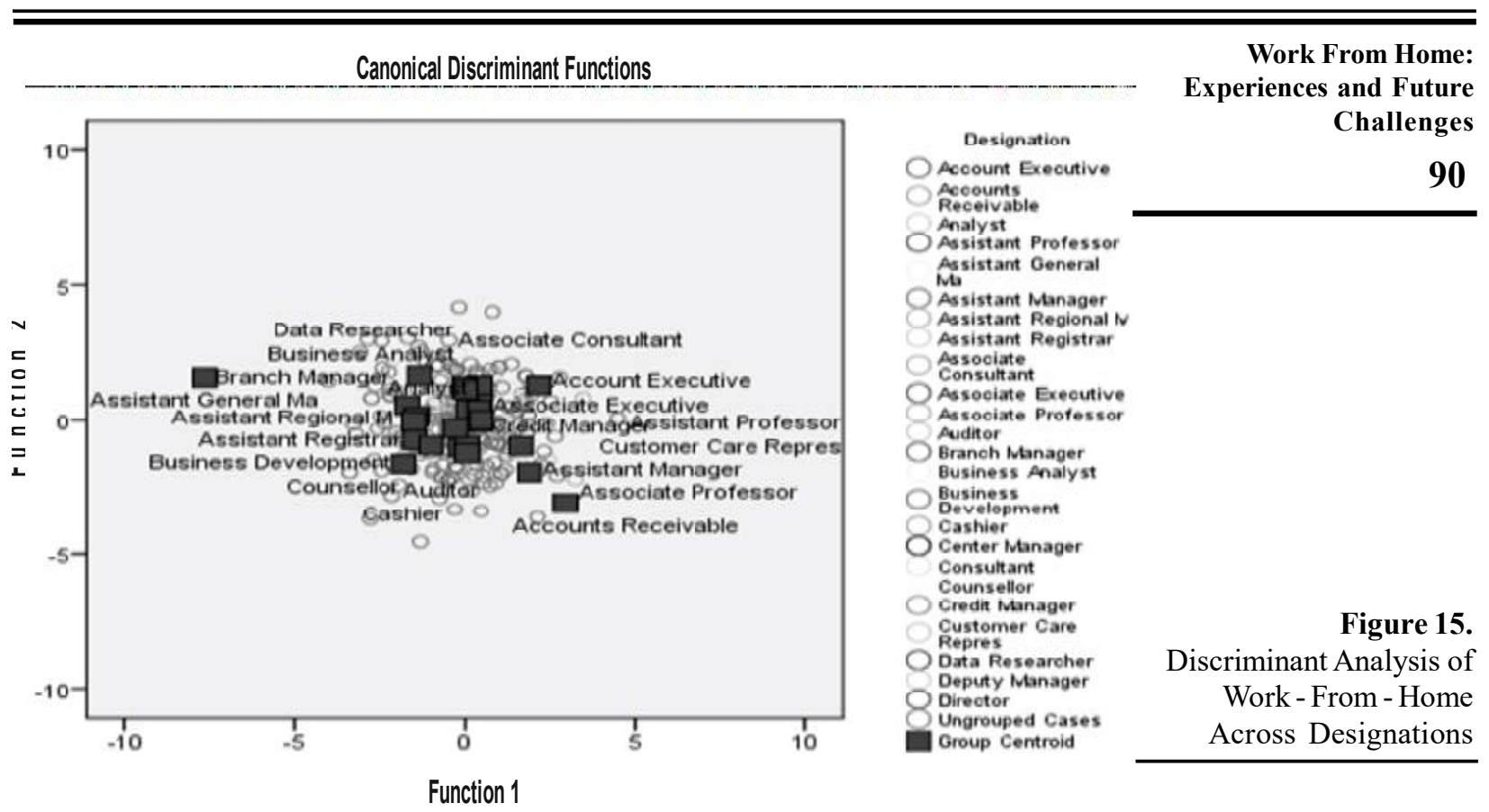

\section{Finding, conclusion, and recommendations}

In a fast-paced developing country like India, a huge number of employees in the services sector are looking forward to their organizations to introduce Work - From - Home policy to be implemented on a regular/occasional basis after lifting the lockdown in India, where WFH was an alien concept. Work from home will be difficult for the organization which relies more on their employees to put in regular shifts and requires more physical coordination among them. In the long term, it will foster better-managed businesses in India-and fewer automobiles logjammed on streets. This would be healthy both in terms of employees' work-life balance in India's untidy and congested metros.

The significant contribution of this research is the identification of the factors and preferences of work from home of Indian employees across various industries/sectors, and demographic variables like age, gender, marital status, family background. The research also explored the experiences and future challenges of work from home experiment from Indian perspectives from pandemic Coronavirus and consequent lockdown. The investigation of experimental data recommended that a combination of the above-mentioned factors across industries explains a significant part of the variance in work from home conclusions. Therefore, these factors can be taken into consideration in future studies and implementation of work from home in Indian organizations.

COVID - 19 has forever changed the experiences of being an employee or an HR. Organizations may implement and continue WFH arrangements in the coming future (in selected sectors/ industries). However, before implementing the WHF arrangement, employers should assess the possibilities and sustainability of productivity, retention, and the psychological wellbeing of employees. HR can evaluate the infrastructural amenities and tools existing for WFH, such as Internet connectivity and the availability of stable power supply, safety, and health in the domestic environment, living arrangements of employees. Now, HR's role shall be more empathetic as they need to consider the factors such as, child or dependent care responsibilities on employees, relationship stress or domestic violence, long-term health situations or debilities, mental health or probable future apprehensions that could arise through a work from home. 


\section{GBR}

Vol. 16

7. References

Adisa, T., Gbolahan, G. \& Ellis, L.C.O. (2016), "Work-family balance: A case analysis of coping strategies adopted by nigerian and british working mothers", Gender in Management. 31. 10.1108/GM-01-2016-0010

Bailey, D. and Kurland, N. (2002), "A review of telework research: findings, new directions, and lessons for the study of modern work", Journal of Organizational Behavior. Vol. 23, pp. 383 - 400. 10.1002/job. 144

Friedman, S.D. (2014), "Work home community self skills for integrating every part of your life", Harvard Business Review, Vol. 92 No. 9, pp. 111-114.

Glen E. Kreiner, Elaine C. Hollensbe, Mathew L. Sheep (2009), "Balancing borders and bridges: negotiating the work-home interface via boundary work tactics", Academy of Management Journal, Vol. 52 No. 4, https://doi.org/10.5465/amj.2009.43669916.

Grant, C.A., Wallace, L.M., and Spurgeon, P.C. (2013), "An exploration of the psychological factors affecting remote e? worker's job effectiveness, wellbeing, and work-life balance", Employee Relations, Vol. 35 No. 5, pp.527-546.

Grant-Vallone, E. J., \& Ensher, E. A. (2011), "Opting In Between: Strategies Used by Professional Women With Children to Balance Work and Family", Journal of Career Development, Vol. 38 No. 4, 331-348. https://doi.org/10.1177/0894845310372219.

Mayo, M., Pastor, J. C., \& Sanz, A. I. (2008), "Enabling managers to achieve work-family balance: a demands-control model of housework behavior and family satisfaction", IE Business School Working Paper, WP08-20, pp. 1-14

Morgan, R. E. (2004), "Teleworking: an assessment of the benefits and challenges", European Business Review, Vol. 16 No. 4, pp. 344-357.

Nilles, J. M. (1975), "Telecommunications and organisational decentralization", Transactions on Communications, Vol. 23, No.10, pp. 1142-1147.

Toffler, A. (1980), The Third Waze, William Morrow, New York.

Walker, A., Wang, C. and Redmond, J. (2008), "Women and work-life balance: is home-based business ownership the solution?", Equal Opportunity International, Vol.27 No. 3. 